Article

\title{
Profiling and Pharmacokinetic Studies of Alkaloids in Rats After Oral Administration of Zanthoxylum nitidum Decoction by UPLC-Q-TOF-MS/MS and HPLC-MS/MS
}

\author{
Aihua Huang ${ }^{1,2}$, Yuguang $\mathrm{Chi}^{2}$, Jiawei Liu ${ }^{1}$, Mincun Wang ${ }^{2}$, Jialiang Qin ${ }^{1}$, Lijuan $\mathrm{Ou}^{2}$, \\ Weiwen Chen ${ }^{1}$, Zhongxiang Zhao ${ }^{2}$, Ruoting Zhan ${ }^{1, *}$ and Hui $\mathrm{Xu}^{1 \text {,* }}$ \\ 1 Key Laboratory of Ministry of Education, Research Center of Chinese Herbal Resources and Engineering, \\ Guangzhou University of Chinese Medicine, Guangzhou 510006, China; hah2008@gzucm.edu.cn (A.H.); \\ liujw@gzucm.edu.cn (J.L.); liang8133466@163.com (J.Q.); chenww@gzucm.edu.cn (W.C.) \\ 2 School of Pharmaceutical Sciences, Guangzhou University of Chinese Medicine, Guangzhou 510006, China; \\ ygchi@gzucm.edu.cn (Y.C.); 13312587641@163.com (M.W.); oulijuan@gzucm.edu.cn (L.O.); \\ zzx37@163.com (Z.Z.) \\ * Correspondence: zhanrt@gzucm.edu.cn (R.Z.); zyfxsherry@gzucm.edu.cn (H.X.); \\ Tel./Fax: +86-20-3935-8331 (R.Z. \& H.X.)
}

Received: 25 December 2018; Accepted: 1 February 2019; Published: 7 February 2019

\begin{abstract}
Zanthoxylum nitidum (Roxb.) DC (Rutaceae), called as "liangmianzhen" in China, is well known for its anti-inflammation and analgesic effect. Alkaloids are its main active constituents. However, little has been known about the absorption of main alkaloids in vivo. In this study, an ultra-performance liquid chromatography coupled with quadrupole-time-of-flight mass spectrometry was employed for identification of absorbed alkaloids in rats after oral administration of Z. nitidum decoction. By analyzing the fragmentation patterns, a total of nineteen alkaloids were exactly or tentatively identified in rat plasma after treatment, of which magnoflorine, $\alpha$-allocryptopine, and skimmianine are dominant. Moreover, a high performance liquid chromatography coupled mass spectrometry method was developed for simultaneous quantification of magnoflorine, $\alpha$-allocryptopine, and skimmianine, and successfully applied to pharmacokinetic study in rats after oral administration of $Z$. nitidum decoction. The research would contribute to comprehensive understanding of the material basis and function mechanism of $Z$. nitidum decoction.
\end{abstract}

Keywords: Zanthoxylum nitidum; UPLC-Q-TOF-MS/MS; pharmacokinetic study; HPLC-MS/MS; magnoflorine

\section{Introduction}

Zanthoxylum nitidum (Roxb.) DC (Rutaceae), locally called as "liangmianzhen" belongs to the genus Zanthoxylum of family Rutaceae. Its roots are traditionally used for treating various ailments such as toothache, stomachache, fever, rheumatism, paresis, and boils, and can be used as an insecticide [1]. Our previous studies indicated that Z. nitidum decoction has anti-contusion injury, analgesic, anti-inflammation, anti-gastritis, gastric mucosal protection, and gastrointestinal movement promotion effects [2,3]. Alkaloids are proved to be the major bioactive components of Z. nitidum [4-20]. Recently, alkaloid profiling of Z. nitidum by HPLC-Q-TOF-MS had been reported [21,22]. Until now, up to 50 alkaloids were isolated and identified, which mainly belong to aporphine, benzylisoquinoline, protoberberine, protopine, benzophenanthrindine, and quinoline alkaloids (Table S1). Our study gave similar results. On the other hand, it is generally accepted that only the components absorbed in blood 
might contribute to the therapeutic effects. Despite of critical pharmacological function of Z. nitidum decoction, its absorbed alkaloid profile as well as pharmacokinetic behavior in vivo remain unknown. Moreover, in order to understand the material basis and function mechanism of Z. nitidum decoction, it is necessary to depict the absorption and pharmacokinetics of the major bioactive alkaloids in vivo after oral administration.

Ultra-performance liquid chromatography coupled with quadrupole-time-of-flight mass spectrometry (UPLC-Q-TOF-MS/MS) has been widely applied for characterization of the components in Chinese medicines and prescriptions [23,24]. Owing to its high resolution and sensitivity, UPLC-Q-TOF-MS/MS can provide a simple and efficient approach for speculating unknown components besides identifying the known ones [25]. In this paper, the absorbed alkaloids in vivo were analyzed by UPLC-Q-TOF-MS/MS. Based on the fragmentation patterns of five authentic alkaloids and those reported in literatures, nineteen alkaloids were exactly identified or tentatively identified in rat plasma after oral administration of Z. nitidum decoction. Five of them were reported for the first time in Z. nitidum. Meanwhile, pharmacokinetic behavior of Z. nitidum decoction was further investigated by HPLC-MS/MS for the first time. The study would provide key information for understanding of the function mechanism of Z. nitidum decoction as well as quality control.

\section{Results and Discussion}

\subsection{Identification of Absorbed Alkaloids of Z. nitidum Decocotion in Rat Plasma}

To identify the absorbed alkaloids in vivo, the rat plasma after oral administration of Z. nitidum decotion was analyzed using the target (Table S1) and untarget strategy reported by Zhang et al. [26]. As a result, a total of 19 prototype alkaloids were identified, including 2 aporphinoid, 3 protopine, 7 benzophenanthrindine, and 7 quinoline alkaloids (Table 1). Among 19 compounds, magnoflorine, $\alpha$-allocryptopine, nitdine, chelerythrine, and skimmianine were unambiguously characterized by comparison with authentic standards. Other compounds were tentatively deduced based on accurate mass of quasimolecular, $\mathrm{MS}^{2}$ spectra and fragmentation pathway, and some isomers were further differentiated by considering relative retention time and molecular polarity. The total ion chromatograms (TICs) of these components are shown in Figure 1 and their chemical structures are shown in Figure 2. The extract ion chromatograms (EICs) and MS ${ }^{2}$ spectra are given in Figure S1. 
Table 1. MS data and identification results of the alkaloids in rat plasma after oral administration of Z. nitidum decoction.

\begin{tabular}{|c|c|c|c|c|c|c|c|c|}
\hline NO. & RT (min) & Mass Found & $\begin{array}{r}\text { Error } \\
(\mathrm{ppm})\end{array}$ & Selected ion & Formula & MS $^{2}$ Ions & Identification & Types \\
\hline 1 & $3.2^{*}$ & 518.2016 & 0.3 & {$[\mathrm{M}+\mathrm{H}]^{+}$} & $\mathrm{C}_{26} \mathrm{H}_{32} \mathrm{NO}_{10}$ & $\begin{array}{c}\text { 356.1491, 338.1389 } \\
188.0704\end{array}$ & $\begin{array}{l}\text { glucothalictrisine/ } \\
\text { glucohunnemannine }\end{array}$ & protopine \\
\hline 2 & 4.2 & 342.1702 & -1 & {$[\mathrm{M}]^{+}$} & $\mathrm{C}_{20} \mathrm{H}_{24} \mathrm{NO}_{4}$ & $297.1111,282.0876,265.0848,237.0900$ & magnoflorine & aporphine \\
\hline 4 & 8.1 & 370.1664 & 0.8 & {$[\mathrm{M}+\mathrm{H}]^{+}$} & $\mathrm{C}_{21} \mathrm{H}_{23} \mathrm{NO}_{5}$ & $\begin{array}{l}352.1555,206.0813 \\
189.0773,188.0704\end{array}$ & $\alpha$-allocryptopine & protopine \\
\hline 5 & $8.4^{*}$ & 260.1284 & 1.1 & {$[\mathrm{M}+\mathrm{H}]^{+}$} & $\mathrm{C}_{15} \mathrm{H}_{17} \mathrm{NO}_{3}$ & $242.1180,188.0709,176.0706,134.0609$ & $\begin{array}{l}\text { 2.2,6-trimethy-3,4,5,6-tetrahydro- } \\
\text { 2H-pyrano[3,2-c]quinoline }\end{array}$ & quinoline \\
\hline 6 & $9.8^{*}$ & 246.0761 & 0.2 & {$[\mathrm{M}+\mathrm{H}]^{+}$} & $\mathrm{C}_{13} \mathrm{H}_{12} \mathrm{NO}_{4}$ & $\begin{array}{c}231.0526,213.0419 \\
185.0471\end{array}$ & $\begin{array}{l}\text { 4-hydroxy-7,8-dimethoxy- } \\
\text { furanquinoline }\end{array}$ & quinoline \\
\hline 7 & 9.9 & 334.1072 & -2 & {$[\mathrm{M}]^{+}$} & $\mathrm{C}_{20} \mathrm{H}_{16} \mathrm{NO}_{4}$ & $319.0831,291.0886,276.0663$ & isofagaridine & benzophenanthrine \\
\hline 8 & 11.3 & 348.1239 & 0.7 & {$[\mathrm{M}]^{+}$} & $\mathrm{C}_{21} \mathrm{H}_{18} \mathrm{NO}_{4}$ & $\begin{array}{l}332.0934,304.0985 \\
290.0806\end{array}$ & nitidine & benzophenanthrine \\
\hline $\begin{array}{c}9 \\
10\end{array}$ & $\begin{array}{c}11.4^{*} \\
11.6\end{array}$ & $\begin{array}{l}260.1283 \\
348.1231\end{array}$ & $\begin{array}{l}0.9 \\
0.5\end{array}$ & $\begin{array}{c}{[\mathrm{M}+\mathrm{H}]^{+}} \\
{[\mathrm{M}]^{+}}\end{array}$ & $\begin{array}{l}\mathrm{C}_{15} \mathrm{H}_{17} \mathrm{NO}_{3} \\
\mathrm{C}_{21} \mathrm{H}_{18} \mathrm{NO}_{4}\end{array}$ & $\begin{array}{c}242.1174,188.0709,176.0706,134.0609 \\
332.0923,304.0975,290.0817\end{array}$ & $\begin{array}{l}\text { ribalinine } \\
\text { chelerythrine }\end{array}$ & $\begin{array}{c}\text { quinoline } \\
\text { benzophenanthrine }\end{array}$ \\
\hline 11 & 12.2 & 276.0656 & 0.5 & {$[\mathrm{M}+\mathrm{H}]^{+}$} & $\mathrm{C}_{17} \mathrm{H}_{9} \mathrm{NO}_{3}$ & $\begin{array}{c}248.0698,218.0594 \\
190.0636\end{array}$ & liriodenine & aporphine \\
\hline 12 & 13.1 & 246.0759 & -0.5 & {$[\mathrm{M}+\mathrm{H}]^{+}$} & $\mathrm{C}_{13} \mathrm{H}_{12} \mathrm{NO}_{4}$ & $\begin{array}{c}231.0526,216.0286 \\
188.0346\end{array}$ & haplopine & quinoline \\
\hline 13 & 15.5 & 260.0916 & 0.9 & {$[\mathrm{M}+\mathrm{H}]^{+}$} & $\mathrm{C}_{14} \mathrm{H}_{13} \mathrm{NO}_{4}$ & $\begin{array}{c}245.0682,227.0575 \\
199.0627\end{array}$ & skimmianine & quinoline \\
\hline 15 & 16.6 & 200.0703 & -1.5 & {$[\mathrm{M}+\mathrm{H}]^{+}$} & $\mathrm{C}_{12} \mathrm{H}_{9} \mathrm{NO}_{2}$ & $\begin{array}{l}185.0471,129.0579 \\
364.1177,354.1321\end{array}$ & dictamine & quinoline \\
\hline 16 & 16.8 & 382.1287 & 0.4 & {$[\mathrm{M}+\mathrm{H}]^{+}$} & $\mathrm{C}_{21} \mathrm{H}_{19} \mathrm{NO}_{6}$ & $\begin{array}{l}349.0947,323.0913 \\
292.0724\end{array}$ & isoarnottianamide & benzophenanthrine \\
\hline 17 & 17.4 & 366.1340 & 1 & {$[\mathrm{M}+\mathrm{H}]^{+}$} & $\mathrm{C}_{21} \mathrm{H}_{19} \mathrm{NO}_{5}$ & $\begin{array}{l}348.1232,333.0983 \\
320.0920,305.0700 \\
292.0739,275.0700\end{array}$ & O-demethyl-becconoline & benzophenanthrine \\
\hline 18 & 17.5 & 382.1288 & 0.7 & {$[\mathrm{M}+\mathrm{H}]^{+}$} & $\mathrm{C}_{21} \mathrm{H}_{19} \mathrm{NO}_{6}$ & $\begin{array}{c}364.1179,354.1334 \\
339.1098,336.1225 \\
292.0718\end{array}$ & arnottianamide & benzophenanthrine \\
\hline 19 & 19.1 & 334.1076 & 0.8 & {$[\mathrm{M}+\mathrm{H}]^{+}$} & $\mathrm{C}_{20} \mathrm{H}_{16} \mathrm{NO}_{4}$ & $319.0848,318.0760,290.0840$ & Norchelerythrine & benzophenanthrine \\
\hline
\end{tabular}

RT mean retention time, and ${ }^{*}$ mean that the compound was reported for the first time in Z. nitidum. 


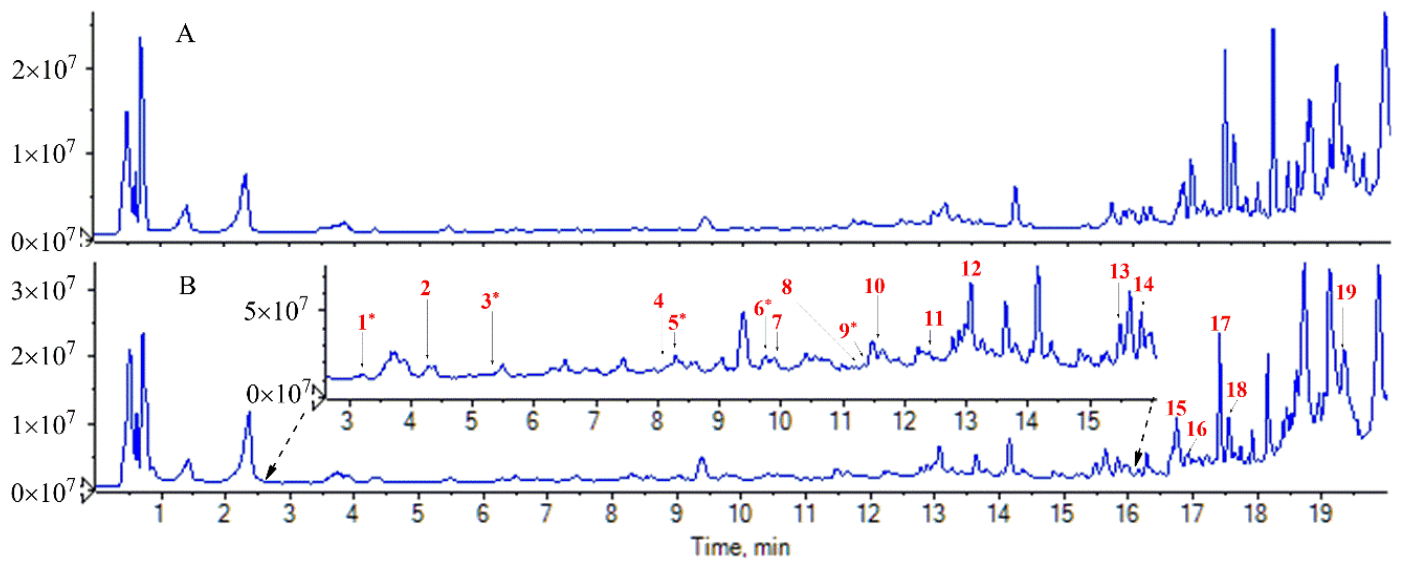

Figure 1. TIC chromatograms. (A) Blank plasma; (B) plasma after oral administration of Z. nitidum decoction.

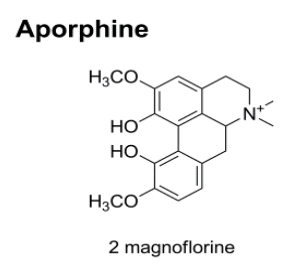

Benzophenanthrine
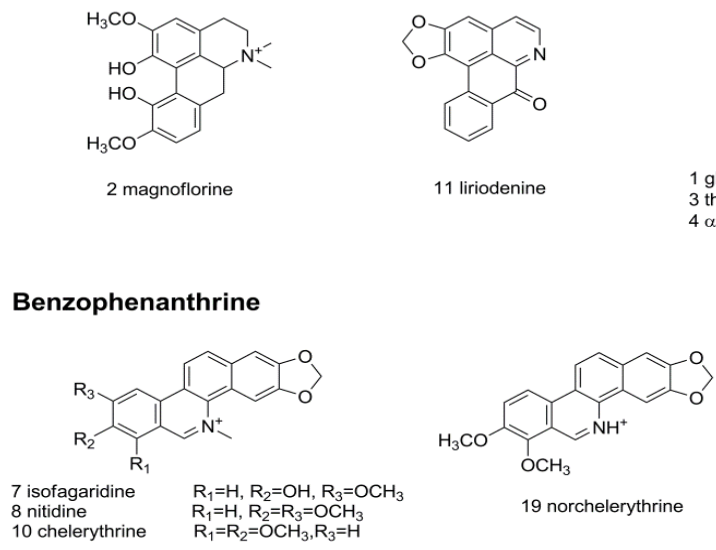

Protopine

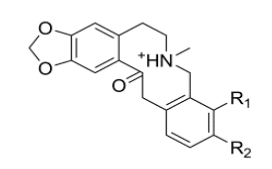

1 glucathalictrisine/glucohunnemannine $\mathrm{R}_{1}=\mathrm{OCH}_{3}, \mathrm{R}_{2}=\mathrm{OGlu} / \mathrm{R}_{1}=\mathrm{OGlu}, \mathrm{R}_{2}=\mathrm{OCH}_{3}$ 3 thalictrisine/hunnemannine $\mathrm{R}_{1}=\mathrm{OCH}_{3}, \mathrm{R}_{2}=\mathrm{OH} / \mathrm{R}_{1}=\mathrm{OH}, \mathrm{R}_{2}=\mathrm{OCH}_{3}$
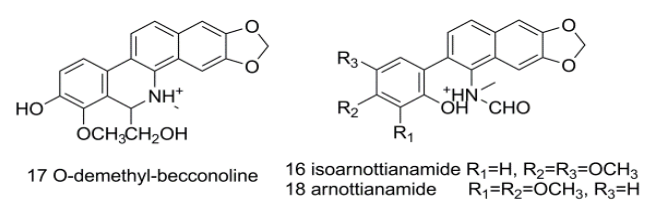

\section{Quinoline}<smiles>[R9]c1ccc2c([R3])c3ccoc3[nH+]c2c1Br</smiles><smiles>CC1(C)Oc2c(c(=O)c3ccccc3n2[13CH2])CC1O</smiles>

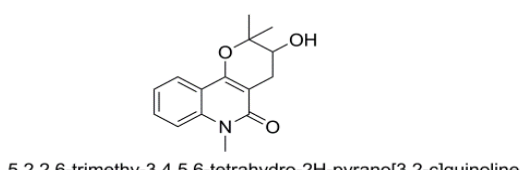

64 -hydroxy-7,8-dimethoxy-furanquinoline $\mathrm{R}_{1}=\mathrm{R}_{2}=\mathrm{OCH}_{3}, \mathrm{R}_{3}=\mathrm{OH}$ 12 haplopine $\quad \mathrm{R}_{1}=\mathrm{OH}, \mathrm{R}_{2}=\mathrm{R}_{3}=\mathrm{OCH}_{3}$ $\begin{array}{ll}13 \text { skimmianine } & \mathrm{R}_{1}=\mathrm{R}_{2}=\mathrm{R}_{3}=\mathrm{OCH}_{3} \\ 14 \gamma \text {-fagarine } & \mathrm{R}_{1}=\mathrm{R}_{3}=\mathrm{OCCH}_{3}, \mathrm{R}_{2}=\mathrm{H}\end{array}$ $\begin{array}{ll}14 \gamma \text {-fagarine } & \mathrm{R}_{1}=\mathrm{R}_{3}=\mathrm{OCH}_{3}, \mathrm{R}_{2}=\mathrm{H} \\ 15 \text { dictamine } & \mathrm{R}_{1}=\mathrm{R}_{2}=\mathrm{H}, \mathrm{R}_{3}=\mathrm{OCH}_{3}\end{array}$

Figure 2. Chemical structure of the alkaloids in rat plasma after oral administration of Z. nitidum decoction.

To facilitate alkaloid identification, $\mathbf{5}$ authentic standards representing $\mathbf{5}$ known alkaloids in Z. nitidum, including one aporphine (magnoflorine), one protopine ( $\alpha$-allocryptopine), two benzophenanthrindine (nitidine and chelerythrine), and one quinoine (skimmianine) were selected and analyzed thoroughly to illustrate the proposed fragmentation pathways for references (Figures 3-5). Among them, the fragment pathway of skimmianine is given in our previous published reference [27]. 


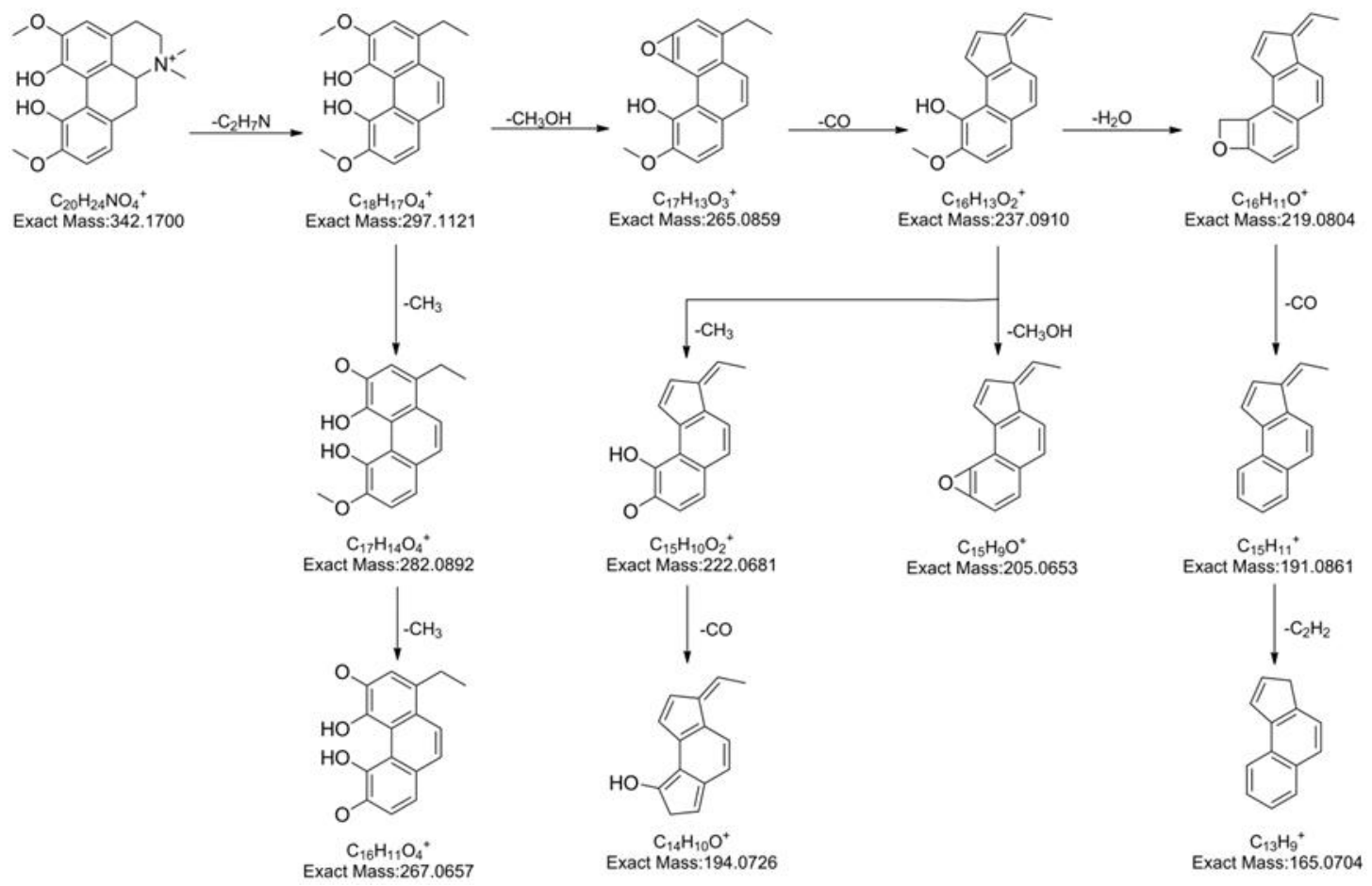

Figure 3. The proposed fragmentation pathway of magnoflorine.

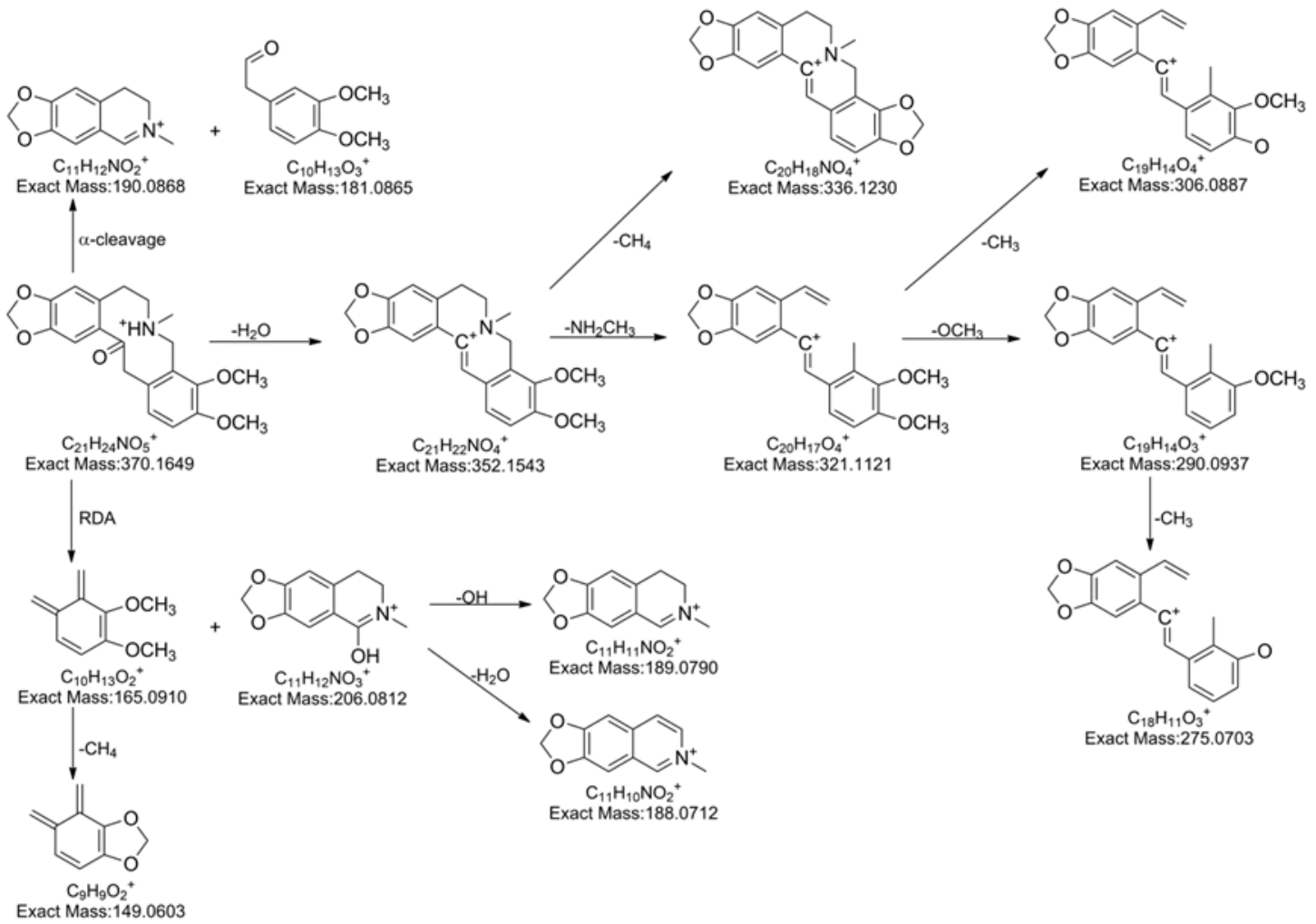

Figure 4. The proposed fragmentation pathway of $\alpha$-allocryptopine. 


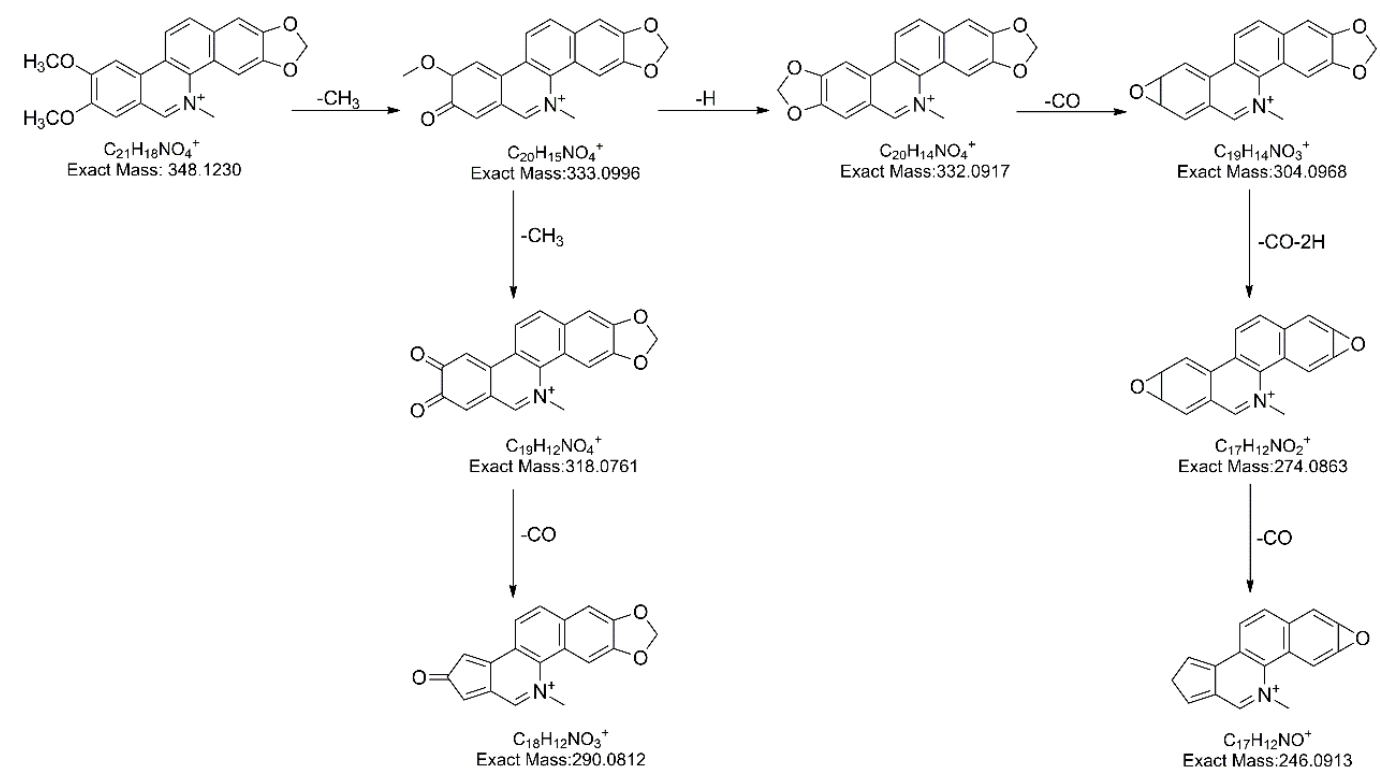

Figure 5. The proposed fragmentation pathway of nitidine.

Magnoflorine was eluted at $4.2 \mathrm{~min}$ with the parent ion at $\mathrm{m} / z 342.1706\left(\mathrm{C}_{20} \mathrm{H}_{24} \mathrm{NO}_{4}{ }^{+}\right)$. The fragment ion at $m / z 297.1121\left(\mathrm{C}_{18} \mathrm{H}_{17} \mathrm{O}_{4}{ }^{+}\right)$was attributed to the elimination of $\left(\mathrm{CH}_{3}\right)_{2} \mathrm{NH}$, which might be an important characteristic of aporphine alkaloid fragmentation pathway [28]. Subsequently, the fragment ion at $m / z 265.0859\left(\mathrm{C}_{17} \mathrm{H}_{13} \mathrm{O}_{3}{ }^{+}\right)$was observed as the base peak due to the loss of $\mathrm{CH}_{3} \mathrm{OH}$. Because of the electron-withdraw inductive effect and the minimal energy of ion, the expulsion of $\mathrm{CH}_{3} \mathrm{OH}$ could occur from vicinal hydroxyl and methoxy groups on $\mathrm{C} 1$ and $\mathrm{C} 2$ [29]. The fragment ion at $m / z 237.0910\left(\mathrm{C}_{16} \mathrm{H}_{13} \mathrm{O}_{2}{ }^{+}\right)$was produced by the neutral loss of $\mathrm{CO}$ from the fragment ion at $m / z 265.0859\left(\mathrm{C}_{17} \mathrm{H}_{13} \mathrm{O}_{3}{ }^{+}\right)$. The removal of $\mathrm{CH}_{3} \mathrm{OH}$ followed by $\mathrm{CO}$ in vicinal hydroxyl and methoxy groups is an important fragmentation pathway of aporphine alkaloids. The fragment ion at $\mathrm{m} / \mathrm{z}$ $237.0910\left(\mathrm{C}_{16} \mathrm{H}_{13} \mathrm{O}_{2}{ }^{+}\right)$further fragmented in three ways. The first way yielded fragment ions at $\mathrm{m} / \mathrm{z}$ 219.0804 $\left(\mathrm{C}_{16} \mathrm{H}_{11} \mathrm{O}^{+}\right), 191.0861\left(\mathrm{C}_{15} \mathrm{H}_{11}{ }^{+}\right), 165.0704\left(\mathrm{C}_{13} \mathrm{H}_{9}{ }^{+}\right)$after the consecutive loss of $\mathrm{H}_{2} \mathrm{O}, \mathrm{CO}$, and $\mathrm{C}_{2} \mathrm{H}_{2}$. The second produced fragment ions at $m / z 222.0681\left(\mathrm{C}_{15} \mathrm{H}_{10} \mathrm{O}_{2}{ }^{+}\right), 194.0726\left(\mathrm{C}_{14} \mathrm{H}_{10} \mathrm{O}^{+}\right)$by the successive elimination of $\mathrm{CH}_{3}$ and $\mathrm{CO}$. While the ion at $m / z 205.0853\left(\mathrm{C}_{15} \mathrm{H}_{9} \mathrm{O}^{+}\right)$was the result of the loss of $\mathrm{CH}_{3} \mathrm{OH}$ through the third way. The fragment ion at $m / z 297.1121\left(\mathrm{C}_{18} \mathrm{H}_{17} \mathrm{O}_{4}{ }^{+}\right)$might break up into the ions at $m / z 282.0892\left(\mathrm{C}_{17} \mathrm{H}_{14} \mathrm{O}_{4}{ }^{+}\right), 267.0657\left(\mathrm{C}_{16} \mathrm{H}_{11} \mathrm{O}_{4}{ }^{+}\right)$via the consecutive loss of $\mathrm{CH}_{3}$ and $\mathrm{CH}_{3}$.

$\alpha$-allocryptopine gave parent ion at $m / z 370.1651\left(\mathrm{C}_{21} \mathrm{H}_{24} \mathrm{NO}_{5}{ }^{+}\right)$at $8.1 \mathrm{~min}$. Subsequently, the parent ion fragmented in three main ways. The first way generated fragment ions at $\mathrm{m} / \mathrm{z}$ $206.0811\left(\mathrm{C}_{11} \mathrm{H}_{12} \mathrm{NO}_{3}{ }^{+}\right), 165.0916\left(\mathrm{C}_{10} \mathrm{H}_{13} \mathrm{O}_{2}{ }^{+}\right)$by retro-Diels-Alder (RDA) reaction. The ion at $\mathrm{m} / \mathrm{z}$ $206.0811\left(\mathrm{C}_{11} \mathrm{H}_{12} \mathrm{NO}_{3}{ }^{+}\right)$further fragmented in two ways, generating fragment ions at $\mathrm{m} / z 189.0780$ $\left(\mathrm{C}_{11} \mathrm{H}_{11} \mathrm{NO}_{2}{ }^{+}\right)$and $188.0704\left(\mathrm{C}_{11} \mathrm{H}_{10} \mathrm{NO}_{2}{ }^{+}\right)$. The loss of $\mathrm{OH}$ led to the formation of ion at $m / z 189.0780$ $\left(\mathrm{C}_{11} \mathrm{H}_{11} \mathrm{NO}_{2}{ }^{+}\right)$, while the ion at $m / z 188.0704\left(\mathrm{C}_{11} \mathrm{H}_{10} \mathrm{NO}_{2}{ }^{+}\right)$was produced via the loss of $\mathrm{H}_{2} \mathrm{O}$. The ions at $m / z 206.0811\left(\mathrm{C}_{11} \mathrm{H}_{12} \mathrm{NO}_{3}{ }^{+}\right), 189.0780\left(\mathrm{C}_{11} \mathrm{H}_{11} \mathrm{NO}_{2}{ }^{+}\right)$and $188.0704\left(\mathrm{C}_{11} \mathrm{H}_{10} \mathrm{NO}_{2}{ }^{+}\right)$were the dominant peaks in the $\mathrm{MS}^{2}$ spectrum of $\alpha$-allocryptopine, indicating that the loss of $\mathrm{H}_{2} \mathrm{O}$ or $\mathrm{OH}$ following the RDA reaction must be the major fragmentation pathway. Concerning the second fragmentation way, the parent ion might undergo $\alpha$-cleavage, producing the ions at $m / z 181.0865\left(\mathrm{C}_{10} \mathrm{H}_{13} \mathrm{O}_{3}{ }^{+}\right)$. Otherwise, the parent ion might break up into the ions at $m / z 352.1543\left(\mathrm{C}_{21} \mathrm{H}_{22} \mathrm{NO}_{4}{ }^{+}\right), 321.1124\left(\mathrm{C}_{20} \mathrm{H}_{17} \mathrm{O}_{4}{ }^{+}\right)$, $290.0937\left(\mathrm{C}_{19} \mathrm{H}_{14} \mathrm{O}_{3}{ }^{+}\right)$and $275.0703\left(\mathrm{C}_{18} \mathrm{H}_{11} \mathrm{O}_{3}{ }^{+}\right)$after the consecutive loss of $\mathrm{H}_{2} \mathrm{O}, \mathrm{NH}_{2} \mathrm{CH}_{3}, \mathrm{OCH}_{3}$ and $\mathrm{CH}_{3}$. The minor peaks at $m / z 336.1230\left(\mathrm{C}_{20} \mathrm{H}_{18} \mathrm{NO}_{4}{ }^{+}\right)$and 306.09.4 $\left(\mathrm{C}_{19} \mathrm{H}_{14} \mathrm{O}_{4}{ }^{+}\right)$might be produced by the loss of $\mathrm{CH}_{4}$ from the ion at $\mathrm{m} / z 352.1543\left(\mathrm{C}_{21} \mathrm{H}_{22} \mathrm{NO}_{4}{ }^{+}\right)$and by the loss of $\mathrm{CH}_{3}$ from the ion at $m / z 321.1124\left(\mathrm{C}_{20} \mathrm{H}_{17} \mathrm{O}_{4}{ }^{+}\right)$, respectively. The loss of $\mathrm{H}_{2} \mathrm{O}$ or OH following the RDA reaction, as well as 
the loss of $\mathrm{H}_{2} \mathrm{O}$, were notable fragmentation pattern of $\alpha$-allocryptopine. This notable fragmentation pattern is consistent with the published fragmentation of protopine-type alkaloids [30].

Two isomers, nitidine and chelerythrine at retention time 11.3 and $11.6 \mathrm{~min}$, respectively, both showed parent ion at $m / z 348.1236\left(\mathrm{C}_{21} \mathrm{H}_{18} \mathrm{NO}_{4}{ }^{+}\right)$and similar fragment pathway. Due to its vicinal methoxy groups, the fragment ion at $m / z 333.0996\left(\mathrm{C}_{20} \mathrm{H}_{15} \mathrm{NO}_{4}{ }^{+}\right), 332.0917\left(\mathrm{C}_{20} \mathrm{H}_{14} \mathrm{NO}_{4}{ }^{+}\right), 304.0968$ $\left(\mathrm{C}_{19} \mathrm{H}_{14} \mathrm{NO}_{3}{ }^{+}\right), 274.0863\left(\mathrm{C}_{18} \mathrm{H}_{12} \mathrm{NO}_{2}{ }^{+}\right)$and $246.0913\left(\mathrm{C}_{17} \mathrm{H}_{12} \mathrm{NO}^{+}\right)$were observed as a result of the elimination of $\mathrm{CH}_{3}, \mathrm{H}, \mathrm{CO}, \mathrm{CH}_{2} \mathrm{O}$ and $\mathrm{CO}$. Another route produced $333.0996\left(\mathrm{C}_{20} \mathrm{H}_{15} \mathrm{NO}_{4}{ }^{+}\right), 318.0761$ $\left(\mathrm{C}_{19} \mathrm{H}_{12} \mathrm{NO}_{4}{ }^{+}\right)$, and $290.0812\left(\mathrm{C}_{18} \mathrm{H}_{12} \mathrm{NO}_{3}{ }^{+}\right)$via the successive loss $\mathrm{CH}_{3}, \mathrm{CH}_{3}$ and $\mathrm{CO}$.

Thus, compounds $(\mathbf{2}, \mathbf{4}, \mathbf{8}, \mathbf{1 0}, \mathbf{1 3})$ were unambiguously identified as magnoflorine, $\alpha$-allocryptopine, nitidine, chelerythrine, and skimmianine, respectively.

Compound 11 displayed the protonated molecule ion at $m / z 276.0655\left(\mathrm{C}_{17} \mathrm{H}_{10} \mathrm{NO}_{3}{ }^{+}\right)$at retention time of $12.2 \mathrm{~min}$. It produced the fragment ions at $m / z 248.0706\left(\mathrm{C}_{16} \mathrm{H}_{10} \mathrm{NO}_{2}{ }^{+}\right), 218.0600\left(\mathrm{C}_{15} \mathrm{H}_{8} \mathrm{NO}^{+}\right)$ and $190.0651\left(\mathrm{C}_{14} \mathrm{H}_{8} \mathrm{~N}^{+}\right)$via the successive loss of $\mathrm{CO}, \mathrm{CH}_{2} \mathrm{O}$ and $\mathrm{CO}$. By comparing with the data in literature, compounds $\mathbf{1 1}$ was tentatively identified as liriodenine [5].

Besides $\alpha$-allocryptopine, two other protopine alkaloids $(\mathbf{1}, \mathbf{3})$ were observed. Compounds $\mathbf{1}$ and 3 were reported for the first time in $\mathrm{Z}$. nitidum. These two compounds were following notable fragmentation pathway: the loss of $\mathrm{H}_{2} \mathrm{O}$ or $\mathrm{OH}$ following the RDA reaction and the loss of $\mathrm{H}_{2} \mathrm{O}$ from parent ion.

Compound 3 exhibited the protonated molecule ion at $m / z 356.1498\left(\mathrm{C}_{20} \mathrm{H}_{22} \mathrm{NO}_{5}{ }^{+}\right)$at retention time of $5.3 \mathrm{~min}, 14 \mathrm{u}$ less than that of $\alpha$-allocryptopine. The fragment ions at $\mathrm{m} / \mathrm{z} 206.0811$ $\left(\mathrm{C}_{11} \mathrm{H}_{12} \mathrm{NO}_{3}{ }^{+}\right), 189.0780\left(\mathrm{C}_{11} \mathrm{H}_{11} \mathrm{NO}_{2}{ }^{+}\right)$and $188.0704\left(\mathrm{C}_{11} \mathrm{H}_{10} \mathrm{NO}_{2}{ }^{+}\right)$resulted from the characteristic losses of $\mathrm{H}_{2} \mathrm{O}$ or $\mathrm{OH}$ following the RDA reaction. The fragment ion at $m / z 338.1389\left(\mathrm{C}_{20} \mathrm{H}_{20} \mathrm{NO}_{4}{ }^{+}\right)$ was the result of the loss of $\mathrm{H}_{2} \mathrm{O}$. Compounds 3 was identified as hunnemannine or thalictrisine [31]. Compound 1 eluted at $3.2 \mathrm{~min}$, had molecular formula $\left(\mathrm{C}_{26} \mathrm{H}_{32} \mathrm{NO}_{10}{ }^{+}\right), 162 \mathrm{u}$ more than that of compound 3. The main fragment ions were identical to those of compound 3. Compound $\mathbf{1}$ was speculated to be glucothalictrisine or glucohunnemannine.

In addition to nitidine and chelerythrine, five benzophenanthridine alkaloids $(7,16,17,18,19)$ were observed. Benzophenanthrindine alkaloids strictly keep their nitrogen inside the highly aromatic ring during fragmentation. The fragment ions were mainly produced by the peripheral loss from methoxyl, methylenedioxy and $\mathrm{N}-\mathrm{CH}_{3}$ groups and so on.

Compound 7 exhibited molecule ion at $m / z 334.1079\left(\mathrm{C}_{20} \mathrm{H}_{16} \mathrm{NO}_{4}{ }^{+}\right)$at retention times of 9.9 min. It produced the fragment ions at $m / z 319.0839\left(\mathrm{C}_{19} \mathrm{H}_{13} \mathrm{NO}_{4}{ }^{+}\right), 291.0890\left(\mathrm{C}_{18} \mathrm{H}_{13} \mathrm{NO}_{3}{ }^{+}\right)$and $276.0655\left(\mathrm{C}_{17} \mathrm{H}_{10} \mathrm{NO}_{3}{ }^{+}\right)$via the successive loss of $\mathrm{CH}_{3}, \mathrm{CO}$ and $\mathrm{CH}_{3}$. Compound 7 was identified as isofagaridine after compared with data in the literature [14].

Eluted at $19.1 \mathrm{~min}$, compound 19 showed the protonated molecular ion at $\mathrm{m} / \mathrm{z} 334.1074$ $\left(\mathrm{C}_{20} \mathrm{H}_{16} \mathrm{NO}_{4}{ }^{+}\right)$. It produced the fragment ions at $319.0839\left(\mathrm{C}_{19} \mathrm{H}_{13} \mathrm{NO}_{4}{ }^{+}\right), 318.0761\left(\mathrm{C}_{19} \mathrm{H}_{12} \mathrm{NO}_{4}{ }^{+}\right)$ and $290.0812\left(\mathrm{C}_{18} \mathrm{H}_{12} \mathrm{NO}_{3}{ }^{+}\right)$due to the successive loss of $\mathrm{CH}_{3}, \mathrm{H}$ and $\mathrm{CO}$, suggesting that compound 19 contained vicinal methoxy groups. Compound 19 was identified as norchelerythrine after compared with the literature [6].

Compound 17 was eluted at $17.4 \mathrm{~min}$, and displayed the protonated molecule ion at $\mathrm{m} / \mathrm{z} 366.1336$ $\left(\mathrm{C}_{21} \mathrm{H}_{20} \mathrm{NO}_{5}{ }^{+}\right)$. It produced the fragment ions at $\mathrm{m} / z 348.1220\left(\mathrm{C}_{21} \mathrm{H}_{18} \mathrm{NO}_{4}{ }^{+}\right), 320.0917\left(\mathrm{C}_{19} \mathrm{H}_{14} \mathrm{NO}_{4}{ }^{+}\right)$ via the successive loss of $\mathrm{H}_{2} \mathrm{O}$ and $\mathrm{C}_{2} \mathrm{H}_{4}$ on $\mathrm{C} 8$ and $\mathrm{N}$, respectively. Compound $\mathbf{1 7}$ was identified as 10-O-demethybocconoline [17].

Compounds 16 and 18 were deduced to be isoarnottianamide and arnottianamide [5]. These two compounds were derivatives of benzophanthridine containing N-methylformamide group, whose mass spectrum a minor peak corresponding to the loss of $\mathrm{HCONHCH}_{3}$ was observed. Compounds $\mathbf{1 6}$ and 18 displayed the same protonated molecule ion at $m / z 382.1291\left(\mathrm{C}_{21} \mathrm{H}_{20} \mathrm{NO}_{6}{ }^{+}\right)$at retention times of 16.8 and $17.5 \mathrm{~min}$, respectively. Both of them produced the fragment ions at $364.1185\left(\mathrm{C}_{20} \mathrm{H}_{20} \mathrm{NO}_{5}{ }^{+}\right)$ and $323.0913\left(\mathrm{C}_{18} \mathrm{H}_{12} \mathrm{NO}_{3}{ }^{+}\right)$resulted from the loss of $\mathrm{H}_{2} \mathrm{O}$ and $\mathrm{HCONHCH}_{3}$, respectively. 
Besides skimmianine, six quinoline alkaloids $(5, \mathbf{6}, \mathbf{9}, \mathbf{1 2}, \mathbf{1 4}, \mathbf{1 5})$ were detected. Compounds 5, 6, and 9 were reported for the first time in Z. nitidum.

Compounds $(6,12,14,15)$ were furanquinoline alkanoids. For furanquinoline compounds containing vicinal methoxy groups at $\mathrm{C} 7$ and $\mathrm{C} 8$, the successive loss of $\mathrm{H}_{2} \mathrm{O}$ following $\mathrm{CH}_{3}$ was a typical characteristic [27]. The main fragment pattern of the other furanquinoline alkanoids was the loss of $\mathrm{CH}_{3}, \mathrm{CO}$, and $\mathrm{CO}$, the final loss of $\mathrm{CO}$ might come from phenolic hydroxyl or furan ring [32]. Compounds 6 and 12 displayed the same protonated molecule ion at $m / z 246.0761\left(\mathrm{C}_{13} \mathrm{H}_{12} \mathrm{NO}_{4}{ }^{+}\right)$ at retention times of 9.8 and $13.1 \mathrm{~min}$, respectively. Compound 6 yielded the fragment ions at $231.0531\left(\mathrm{C}_{12} \mathrm{H}_{9} \mathrm{NO}_{4}{ }^{+}\right), 213.0419\left(\mathrm{C}_{12} \mathrm{H}_{7} \mathrm{NO}_{3}{ }^{+}\right)$and $185.0470\left(\mathrm{C}_{11} \mathrm{H}_{7} \mathrm{NO}_{2}{ }^{+}\right)$via the consecutive loss of $\mathrm{CH}_{3}, \mathrm{H}_{2} \mathrm{O}$ and $\mathrm{CO}$. The fragmentation pathway was like that of skimmianine, suggesting the existence of adjacent methoxy groups at $\mathrm{C} 7$ and C8. Compound 6 was identified as 4-hydroxy-7, 8-dimethoxyl-furanquinoline [27]. Compound 12 generated the fragment ions at $231.0531\left(\mathrm{C}_{12} \mathrm{H}_{9} \mathrm{NO}_{4}{ }^{+}\right)$, $216.0289\left(\mathrm{C}_{11} \mathrm{H}_{6} \mathrm{NO}_{4}{ }^{+}\right)$, and $188.0327\left(\mathrm{C}_{10} \mathrm{H}_{6} \mathrm{NO}_{3}{ }^{+}\right)$due to the consecutive losses of $\mathrm{CH}_{3}, \mathrm{CH}_{3}$, and $\mathrm{CO}$. The fragmentation pathway showed that compound 12 do not possess adjacent methoxy groups at $\mathrm{C} 7$ and $\mathrm{C} 8$. So, it might contain $\mathrm{C} 7-\mathrm{OH}$ or $\mathrm{C} 8-\mathrm{OH}$. Because $\mathrm{C} 7-\mathrm{OH}$ is less polar than $\mathrm{C} 8-\mathrm{OH}$, isomer with $\mathrm{C} 7-\mathrm{OH}$ must be eluted later. Comparing the retention time of two isomers with our previous published reference [27], compound $\mathbf{1 2}$ was speculated as the isomer with C7-OH. Thus, compound $\mathbf{1 2}$ was identified as haplopine [7].

Compound 14 displayed the protonated molecule ion at $m / z 230.0817\left(\mathrm{C}_{13} \mathrm{H}_{12} \mathrm{NO}_{3}{ }^{+}\right)$at retention times of $15.8 \mathrm{~min}$. The subsequent fragment ions at $m / z 215.0575\left(\mathrm{C}_{12} \mathrm{H}_{9} \mathrm{NO}_{3}{ }^{+}\right), 200.0341\left(\mathrm{C}_{11} \mathrm{H}_{6} \mathrm{NO}_{3}{ }^{+}\right)$, $172.0391\left(\mathrm{C}_{10} \mathrm{H}_{6} \mathrm{NO}_{2}{ }^{+}\right), 144.0403\left(\mathrm{C}_{9} \mathrm{H}_{6} \mathrm{NO}^{+}\right)$, and $116.0499\left(\mathrm{C}_{8} \mathrm{H}_{6} \mathrm{~N}^{+}\right)$were observed as a result of the losses of $\mathrm{CH}_{3}, \mathrm{CH}_{3}, \mathrm{CO}, \mathrm{CO}$ and $\mathrm{CO}$. Compound 14 was identified as $\gamma$-fagarine [16].

Compound 15 yielded the protonated molecule ion at $m / z 200.0706\left(\mathrm{C}_{12} \mathrm{H}_{10} \mathrm{NO}_{2}{ }^{+}\right)$at retention times of $16.6 \mathrm{~min}$. The fragment ions at $m / z 185.0471\left(\mathrm{C}_{11} \mathrm{H}_{7} \mathrm{NO}_{2}{ }^{+}\right), 157.0522\left(\mathrm{C}_{10} \mathrm{H}_{7} \mathrm{NO}^{+}\right)$and 129.0573 $\left(\mathrm{C}_{9} \mathrm{H}_{7} \mathrm{~N}^{+}\right)$resulted from the consecutive losses of $\mathrm{CH}_{3}, \mathrm{CH}_{3}$ and $\mathrm{CO}$. Compound 15 was tentatively identified as dictammine [9].

Compounds 5 and 9 eluted at 8.4 and $11.4 \mathrm{~min}$, respectively, must contain dihydropyran ring with hydroxyl. Both shared the same protonated molecule ion at $m / z 260.1287\left(\mathrm{C}_{15} \mathrm{H}_{18} \mathrm{NO}_{3}{ }^{+}\right)$. These two compounds all produced the fragment ions corresponding to the loss of $\mathrm{H}_{2} \mathrm{O}$ and $\mathrm{C}_{4} \mathrm{H}_{8} \mathrm{O}$. The loss of $\mathrm{C}_{4} \mathrm{H}_{8} \mathrm{O}$ were produced by RDA reaction of dihydropyran ring. Therefore, compounds 5 and 9 were identified as 3-hydroxy, 2, 2, 6-trimethyl-3, 4, 5, 6-tetrahydro-2H-pyrano [3, 2-c] quinoline 5-one and ribalinine, which had been reported to be isolated from Skimmia laureola Hook, a plant of family Rutaceae [33].

\subsection{Quantitative Method Validation}

After oral administration of Z. nitidum decoction, a total of 19 prototype alkaloids were identified. Considering the quality control component of Z. nitidum suggested by Chinese Pharmacopoeia 2015, content in Z. nitidum, plasma exposure level and the availability of reference standard, magnoflorine, $\alpha$-allocryptopine, nitdine, chelerythrine, and skimmianine were selected to perform pharmacokinetic experiments by HPLC-MS/MS. However, the results of the preliminary experiment showed that nitidine and chelerythrine had poor absorption, as reported in the literatures [34,35]. Moreover, obvious interference was observed from endogenous material at the rentention times of nitidine and chelerythrine during the chromatographic separation, despite various sample preparation methods were applied. Finally, magnoflorine, $\alpha$-allocryptopine, and skimmianine were selected for the further pharmacokinetic study. The corresponding quantification method using HPLC-MS/MS were developed.

The typical chromatograms of blank plasma, blank plasma spiked with three analytes and internal standard (IS), and plasma after oral administration of Z. nitidum decoction were shown in Figure 6. No obvious interference was observed from endogenous material at the rentention times of analytes and IS. As shown in Table 2, magnoflorine, $\alpha$-allocryptopine, and skimmianine showed good 
linearity $(r>0.999)$ over the linear range. The lower limit of quantification (LLOQ) of magnoflorine, $\alpha$-allocryptopine and skimmianine were 2,2 , and $0.5 \mathrm{ng} / \mathrm{mL}$, respectively. The intra- and inter-day precision and accuracy were summarized in Table 3 . All analytes displayed relative standard deviation (RSD\%) below $11.23 \%$ and relative error (RE\%) ranged from $8.05 \%$ to $11.23 \%$, which were within the acceptable criteria. The extraction recovery of magnoflorine, $\alpha$-allocryptopine and skimmianine were in the range of $89.87-98.32 \%$ and IS was $93.90 \%$. The matrix effects of three analytes were in the range of $92.73-108.46 \%$ and IS was $93.88 \%$. The stability of analytes under four storage conditions were assessed and the results were listed in Table 4 . All analytes exhibited RSD $\%$ below $11.32 \%$ and RE\% ranged from $10.00 \%$ to $12.53 \%$, indicating that the analytes were stable. In conclusion, the developed method was validated and satisfactory for pharmacokinetic study.
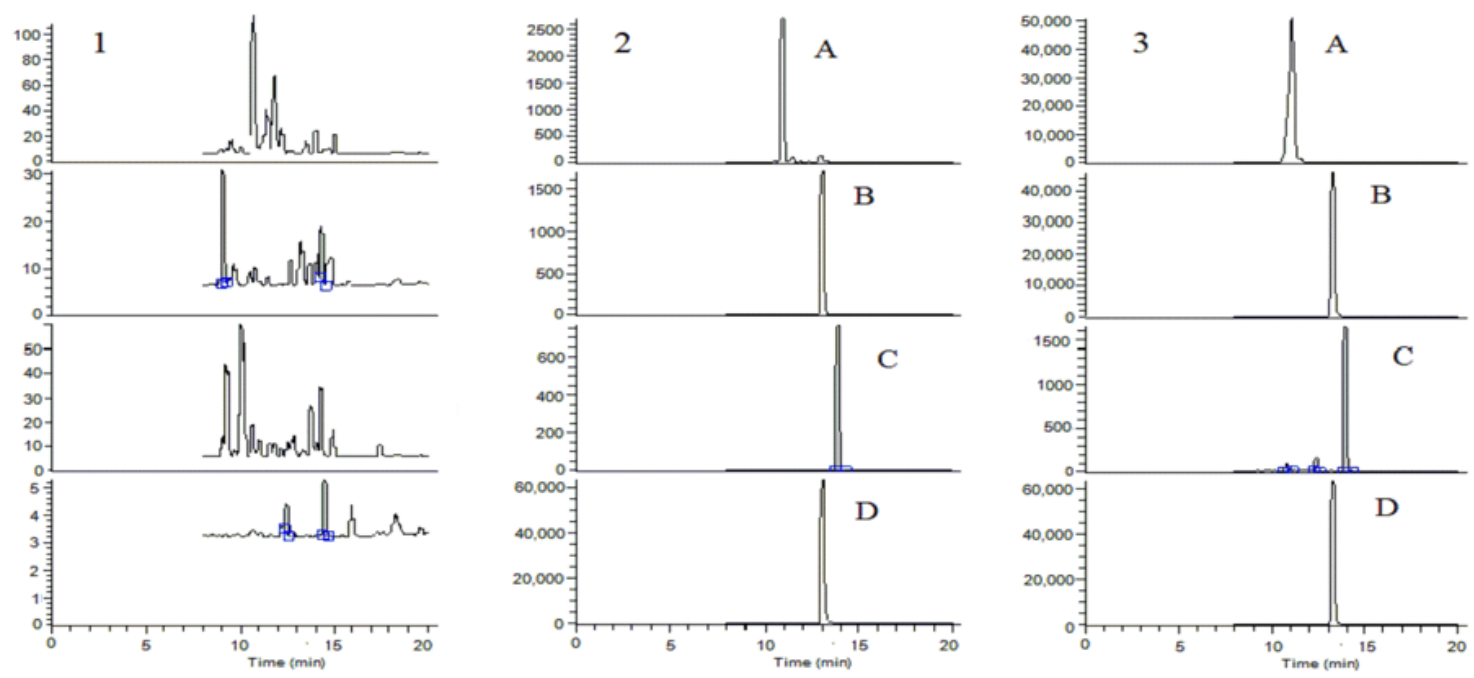

Figure 6. The typical SRM chromatograms. 1. Blank plasma; 2. Blank plasma spiked with three analytes at LLOQ level and IS; 3. Plasma collected at $1 \mathrm{~h}$ after oral administration of Z. nitidum decoction. A. Magnoflorine, B. $\alpha$-allocryptopine, C. Skimmianine and D. internal standard (IS).

Table 2. Regression equation, correlation coefficients, linear range and lower limit of quantification (LLOQ) of analytes.

\begin{tabular}{|c|c|c|c|c|c|c|}
\hline \multirow[b]{2}{*}{ Analyte } & \multirow{2}{*}{$\begin{array}{c}\text { Linear } \\
\text { Regression } \\
\text { Equation }\end{array}$} & \multirow[b]{2}{*}{$\mathbf{r}$} & \multirow{2}{*}{$\begin{array}{l}\text { Linear } \\
\text { Range } \\
(\mathrm{ng} / \mathrm{mL})\end{array}$} & \multicolumn{3}{|c|}{ LLOQ } \\
\hline & & & & $\begin{array}{c}\text { Concentration } \\
(\mathrm{ng} / \mathrm{mL})\end{array}$ & $\begin{array}{c}\text { RSD } \\
(\%)\end{array}$ & RE (\%) \\
\hline magnoflorine & $y=0.011 x+0.018$ & 0.9990 & $2-200$ & 2 & 8.72 & -6.88 \\
\hline$\alpha$-allocryptopine & $y=0.012 x+0.010$ & 0.9995 & $2-200$ & 2 & 13.04 & -7.25 \\
\hline skimmianine & $y=0.014 x-0.010$ & 0.9996 & $0.5-50$ & 0.5 & 14.81 & 5.63 \\
\hline
\end{tabular}

Table 3. Precision, accuracy, extraction recovery and matrix effect of analytes in rat plasma $(n=6)$.

\begin{tabular}{|c|c|c|c|c|c|c|c|c|}
\hline \multirow{2}{*}{ Analyte } & \multirow{2}{*}{$\begin{array}{c}\text { Concentration } \\
(\mathrm{ng} / \mathrm{mL})\end{array}$} & \multicolumn{2}{|c|}{ Intraday } & \multicolumn{2}{|c|}{ Interday } & \multirow{2}{*}{$\begin{array}{c}\text { Extraction } \\
\text { Recovery } \\
(\text { Mean } \pm \text { SD, \%) }\end{array}$} & \multirow{2}{*}{$\begin{array}{c}\text { Matrix Effect } \\
(\text { Mean } \pm \text { SD, \%) }\end{array}$} & \multirow{2}{*}{$\begin{array}{l}\text { Related Matrix } \\
\text { Effect (RSD, \%) }\end{array}$} \\
\hline & & RSD (\%) & RE (\%) & RSD (\%) & RE (\%) & & & \\
\hline \multirow{4}{*}{ magnoflorine } & 5 & 4.22 & -8.05 & 10.0 & 11.03 & $89.87 \pm 7.75$ & $108.46 \pm 9.4$ & 6.51 \\
\hline & 50 & 2.89 & 5.62 & 8.12 & -3.45 & $90.52 \pm 3.16$ & $98.91 \pm 5.59$ & 4.76 \\
\hline & 160 & 6.78 & 3.16 & 5.26 & 6.64 & $95.57 \pm 3.82$ & $94.47 \pm 7.18$ & 5.43 \\
\hline & 5 & 1.83 & 9.33 & 3.96 & 7.56 & $92.68 \pm 5.38$ & $102.38 \pm 8.43$ & 8.37 \\
\hline \multirow[t]{2}{*}{$\alpha$-allocryptopine } & 50 & 3.75 & -3.87 & 5.77 & -1.57 & $96.08 \pm 6.77$ & $99.32 \pm 4.35$ & 7.12 \\
\hline & 160 & 2.23 & 1.82 & 7.02 & -8.02 & $94.30 \pm 4.16$ & $93.82 \pm 5.63$ & 5.56 \\
\hline \multirow{3}{*}{ skimmianine } & 1 & 2.62 & 4.41 & 4.01 & 6.33 & $93.41 \pm 4.41$ & $101.10 \pm 6.42$ & 6.39 \\
\hline & 10 & 2.84 & 6.51 & 11.23 & -7.75 & $98.32 \pm 6.47$ & $99.39 \pm 5.84$ & 8.41 \\
\hline & 32 & 3.56 & 4.97 & 2.65 & 4.39 & $94.06 \pm 3.56$ & $92.73 \pm 5.52$ & 5.17 \\
\hline
\end{tabular}


Table 4. Stability of analytes in rat plasma $(n=6)$.

\begin{tabular}{|c|c|c|c|c|c|c|c|c|c|}
\hline \multirow{2}{*}{ Analyte } & \multirow{2}{*}{$\begin{array}{l}\text { Concentration } \\
\quad(\mathrm{ng} / \mathrm{mL})\end{array}$} & \multicolumn{2}{|c|}{$\begin{array}{c}\text { Three Freeze-Thaw } \\
\text { Cycle }\end{array}$} & \multicolumn{2}{|c|}{$\begin{array}{l}8 \mathrm{~h} \text { at Room } \\
\text { Temperature }\end{array}$} & \multicolumn{2}{|c|}{$24 \mathrm{~h}$ at $4^{\circ} \mathrm{C}$} & \multicolumn{2}{|c|}{40 Days at $=-80^{\circ} \mathrm{C}$} \\
\hline & & RSD (\%) & RE (\%) & $\begin{array}{c}\text { RSD } \\
(\%)\end{array}$ & RE (\%) & $\begin{array}{c}\text { RSD } \\
(\%)\end{array}$ & RE (\%) & $\begin{array}{c}\text { RSD } \\
(\%)\end{array}$ & RE (\%) \\
\hline \multirow{3}{*}{ magnoflorine } & 5 & 7.53 & -10.00 & 8.25 & -5.14 & 4.46 & -5.59 & 6.43 & 10.17 \\
\hline & 50 & 4.58 & 11.03 & 3.26 & 6.87 & 3.81 & 9.24 & 3.68 & -8.92 \\
\hline & 160 & 5.54 & 9.16 & 1.53 & 5.74 & 9.95 & 4.61 & 4.15 & 5.74 \\
\hline \multirow{3}{*}{$\alpha$-allocryptopine } & 5 & 8.61 & 8.97 & 6.55 & 12.53 & 2.07 & 2.99 & 5.88 & 8.59 \\
\hline & 50 & 6.62 & -5.58 & 3.68 & -7.13 & 6.14 & -6.21 & 3.71 & -4.82 \\
\hline & 160 & 1.19 & 4.24 & 1.59 & 3.27 & 1.26 & 7.75 & 2.73 & -6.91 \\
\hline \multirow{3}{*}{ skimmianine } & 1 & 9.22 & 10.43 & 11.06 & -9.41 & 8.18 & 9.47 & 8.57 & 9.69 \\
\hline & 10 & 8.51 & -5.95 & 10.44 & 6.62 & 11.32 & -4.39 & 9.92 & -6.48 \\
\hline & 32 & 7.13 & -9.01 & 8.43 & 9.51 & 4.31 & -1.09 & 8.01 & -4.07 \\
\hline
\end{tabular}

\subsection{Pharmacokinetic Study}

The validated HPLC-MS/MS method was successfully applied for the pharmacokinetic study of magnoflorine, $\alpha$-allocryptopine, and skimmianine in rat plasma after oral administration of Z. nitidum decoction. The plasma concentration-time curve was shown in Figure 7. The main pharmacokinetic parameters were processed by Drug and Statistics (DAS) 2.0 software and listed in Table 5.
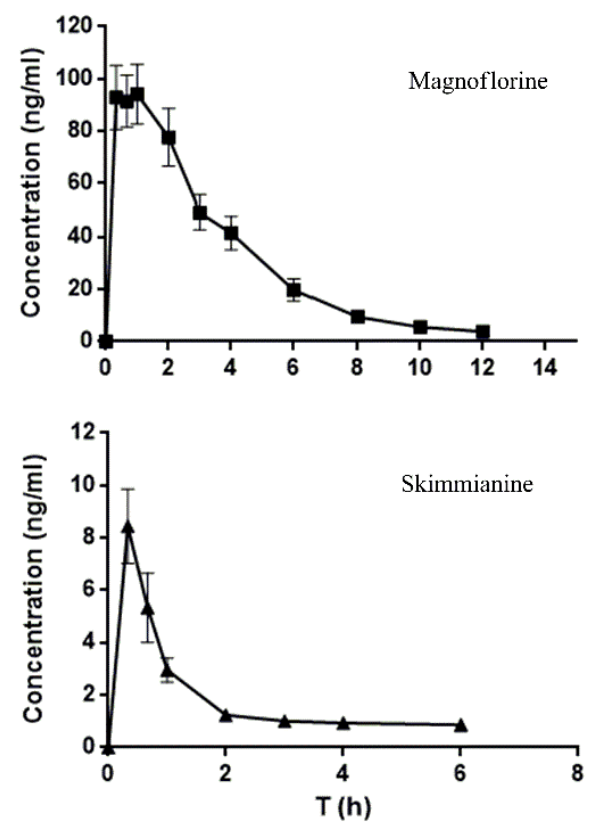

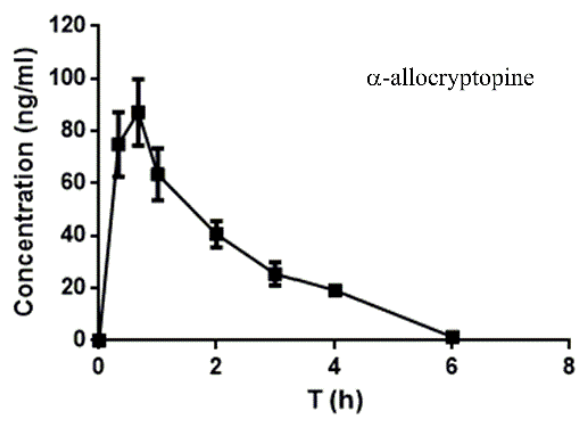

Figure 7. Plasma concentration-time curves of analytes.

Table 5. Pharmacokinetic parameters of analytes in rats after oral administration.

\begin{tabular}{cccc}
\hline \multirow{2}{*}{ Parameters } & \multicolumn{3}{c}{ Analytes (Mean $\pm \mathrm{SD}, \boldsymbol{n = 6 )}$} \\
\cline { 2 - 4 } & Magnoflorine & $\boldsymbol{\alpha}$-ALlocryptopine & Skimmianine \\
\hline Cmax $(\mathrm{ng} / \mathrm{mL})$ & $112.69 \pm 18.79$ & $100.28 \pm 49.91$ & $8.91 \pm 1.89$ \\
$\operatorname{Tmax}(\mathrm{h})$ & $1.05 \pm 0.71$ & $0.47 \pm 0.13$ & $0.38 \pm 0.12$ \\
$\mathrm{~T} 1 / 2(\mathrm{~h})$ & $3.24 \pm 1.31$ & $0.78 \pm 0.17$ & $5.99 \pm 1.62$ \\
AUC0-t $\left(\mathrm{h}^{*} \mathrm{ng} / \mathrm{mL}\right)$ & $408.13 \pm 91.34$ & $180.361 \pm 96.32$ & $11.08 \pm 2.02$ \\
AUC0- $\infty\left(\mathrm{h}^{*} \mathrm{ng} / \mathrm{mL}\right)$ & $437.99 \pm 106.29$ & $186.41 \pm 98.68$ & $17.05 \pm 6.32$ \\
\hline
\end{tabular}

AUC: area under curve.

As shown in Figure 7, the three components were absorbed rapidly after oral administration, with $\mathrm{T}_{\max }$ ranged from 0.38 to $1.05 \mathrm{~h}$. The $\mathrm{C}_{\max }$ of magnoflorine and $\alpha$-allocryptopine were about 
ten times higher than that of skimmianine. Combined with their contents in Z. nitidum decoction (6.7, 1.1 and $0.4 \mathrm{mg} / \mathrm{mL}$ ), the absorption rate of $\alpha$-allocryptopine might be the highest of these three alkaloids. The $T_{1 / 2}$ of magnoflorine, $\alpha$-allocryptopine and skimmianine were $3.24 \pm 1.31,0.78 \pm 0.17$ and $5.99 \pm 1.62 \mathrm{~h}$, respectively. The total exposure area under curve (AUC) $)_{0-\infty}$ of magnoflorine was the largest of the three components. The relatively higher plasma concentration and $\mathrm{AUC}_{0-\infty}$ indicated that magnoflorine and $\alpha$-allocryptopine might have favorable drug-like properities.

Magnoflorine has been reported for its diverse pharmacological properties, such as anti-inflammatory, anti-bacteria and immunomodulatory effects [36-39]. Some of these properties might contributed to anti-inflammation and analgesic effect of Z. nitidum decoction in clinic use. Limited information is known about pharmacological properties of $\alpha$-allocryptopine. Available studies indicate that $\alpha$-allocryptopine possesses antiarrhythmic effects [40-42]. Skimmianine has been reported to possess anti-inflammatory and non-narcotic analgesic effects etc. [43-45], but its plasma concentration and $\mathrm{AUC}_{0-\infty}$ was relatively lower in this study. Whether there exist synergistic action of them needs further investigation.

As for nitidine, due to poor absorption, its functional mechanism in vivo needs further study.

\section{Experimental}

\subsection{Chemical, Reagents and Materials}

The roots of Z. nitidum were collected from Guangdong, China, and authenticated by RT Zhan. Magnoflorine (No. 130611, purity $98.0 \%$ ) and $\alpha$-allocryptopine (No.150510, purity $98.0 \%$ ) were purchased from Sichuan Victory Bio-Technology Ltd. (Chengdu, China) Co., nitidine chloride (No.110848, purity $98.0 \%$ ) and chelerythrine (No.110718, purity 98.0\%) were purchased from the National Institute for the Control of Pharmaceutical and Biological Product (Beijing, China), skimmianine (No.160106, purity $98.0 \%$ ) was purchased from Shanghai yuanmu Bio-Technology Ltd. (Shanghai, China) Co. Acetonitrile and formic acid were of HPLC grade agents and obtained from Merck (Darmstadt, Germany). All other agents were of analytical grade and purchased from Guangzhou Chemical Reagent Factory (Guangzhou, China). Triple deionized water was prepared using a Milli-Q system (Millipore, Billerica, MA, USA). The HyperSep C18 solid-phase extraction (SPE) column (1000 mg, $6 \mathrm{~mL}$ ) was purchased from Thermo Electron Corporation (Waltham, MA, USA).

\subsection{Instrumentation and Analytical Conditions}

\subsubsection{Qualitative Analysis}

The UPLC analysis was performed on a Shimadzu Nexera UHPLC LC-30A system (Shimadzu Corporation, Tokyo, Japan). The separation was executed by an ODS column (Shimadzu, $2.0 \mathrm{~mm}$ i.d. $\times 100 \mathrm{~mm}, 1.9 \mu \mathrm{m})$ maintained at $35^{\circ} \mathrm{C}$. The mobile phase consisted of Solvent A $(0.1 \%$ formic acid solution) and Solvent B ( $0.1 \%$ formic acid acetonitrile). The flow rate was $0.4 \mathrm{~mL} / \mathrm{min}$. The gradient program was as follows: $5-20 \%$ B at $0-10 \mathrm{~min} ; 20-35 \%$ B at $10-15 \mathrm{~min} ; 35-100 \%$ B at $15-20 \mathrm{~min}$.

MS spectra were achieved on an AB SCIEX Triple TOF 5600 (AB Sciex Pte. Ltd., Singapore, Singapore) with electrospray ionization (ESI) source in positive mode. The following parameters of mass spectra were used: source temperature at $500{ }^{\circ} \mathrm{C}$; nebulizer and heater gas pressure at $50 \mathrm{psi}$; curtain gas pressure at $40 \mathrm{psi}$; ion spray voltage at $5500 \mathrm{~V}$; declustering potential at $100 \mathrm{~V}$, collision energy $10 \mathrm{eV}$, and mass range 100-800 amu. The collision energy in "product ion" scan was set at $35 \mathrm{v}$ with a collision energy spread of $10 \mathrm{eV}$. Data acquisition was controlled with AB SCIEX Analyst TF (Version 1.7) software (AB Sciex Pte. Ltd., Singapore, Singapore). Data processing was performed with Peakview (Version 2.0) software (AB Sciex Pte. Ltd., Singapore, Singapore). 


\subsubsection{Quantitative Analysis}

The HPLC analysis performed on a Surveyor plus HPLC system (Thermo Fisher Scientific, Waltham, MA, USA). The separation was executed by a Thermo Accucore aq C18 column $(100 \times$ $2.1 \mathrm{~mm}, 2.6 \mu \mathrm{m}$ ) (Thermo Fisher Scientific, Waltham, MA, USA) maintained at $30^{\circ} \mathrm{C}$. The mobile phase consisted of Solvent A ( $0.1 \%$ formic acid solution) and Solvent B ( $0.1 \%$ formic acid acetonitrile). The flow rate was $0.3 \mathrm{~mL} / \mathrm{min}$. The gradient program was as follows: $5-10 \% \mathrm{~B}$ at $0-5 \mathrm{~min} ; 10-100 \% \mathrm{~B}$ at 5-15 $\mathrm{min} ; 100-5 \% \mathrm{~B}$ at $15-15.1 \mathrm{~min} ; 5 \% \mathrm{~B}$ at $15-20 \mathrm{~min}$.

MS data were achieved on a triple-quadrupole mass spectrometer: TSQ Quantum Access (Thermo Fisher Scientific, Waltham, MA, USA) with electrospray ionization (ESI) source in positive mode. The instrument parameters were as follows: spray voltage at $3000 \mathrm{~V}$, sheath gas and auxiliary gas with a flow of 30 and 5 arbitrary units, capillary temperature at $350{ }^{\circ} \mathrm{C}$, collision gas pressure at $1.0 \mathrm{mTorr}$, skimmer offset at $2 \mathrm{~V}$. The selected reaction monitoring (SRM) transitions used for MS analysis were as follows: $m / z 342 \rightarrow 297$ for magnoflorine, $370 \rightarrow 188$ for $\alpha$-allocryptopine, $260 \rightarrow 227$ for skimmianine, $356 \rightarrow 192$ for IS; the collision energies at $15 \mathrm{eV}$ for magnoflorine, $30 \mathrm{eV}$ for $\alpha$-allocryptopine, skimmianine and IS. The data acquisition and processing was performed with Xcalibur 2.0 software (Thermo Fisher Scientific, Waltham, MA, USA).

\subsection{Preparation of Samples}

\subsubsection{Preparation of Z. nitidum Decoction}

$100 \mathrm{~g}$ of the roots of Z. nitidum were weighed and decocted with $1.2 \mathrm{~L}$ of water for $3 \mathrm{~h}$. The filtrate was collected and residue was decocted in $1.2 \mathrm{~L}$ of water for $2 \mathrm{~h}$ again. Subsequently, the filtrates from each decoction were combined and concentrated to $50 \mathrm{~mL}$. The contents of magnoflorine, $\alpha$-allocryptopine, nitidine, chelerythrine, and skimmianine in Z. nitidum decoction were 6.7, 1.1, 1.8, 3.5 , and $0.4 \mathrm{mg} / \mathrm{mL}$, respectively.

\subsubsection{Preparation of Plasma Samples}

Qualitative Analysis

The $2 \mathrm{~mL}$ plasma sample was loaded on a pretreated SPE column which was eluted with $20 \mathrm{~mL}$ methanol followed by $20 \mathrm{~mL}$ water. After being washed off by $6 \mathrm{~mL}$ of water, the cartridge was eluted using $6 \mathrm{~mL}$ methanol. The methanol eluting was evaporated to dryness at $35^{\circ} \mathrm{C}$ in vacuum using SpeedVac Concentration (Savant SPD 1010, Thermo scientific). The residue was reconstituted in $300 \mu \mathrm{L}$ acetonitrile and water $(50: 50, v / v)$ and centrifuged at $13,000 \mathrm{rpm}(15,493 \times g)$ for $15 \mathrm{~min}$.

\section{Quantitative Analysis}

$100 \mu \mathrm{L}$ plasma sample, $10 \mu \mathrm{L}$ IS solution $(200 \mathrm{ng} / \mathrm{mL})$ and $300 \mu \mathrm{L}$ acetonitrile were added to a $1.5 \mathrm{~mL}$ eppendorf tube and vortex-mixed for $5 \mathrm{~min}$, then centrifuged at $13,000(15,493 \times \mathrm{g}) \mathrm{rpm}$ for 10 $\mathrm{min}$. The supernatant was transferred into another eppendorf tube and evaporated to dryness at $35^{\circ} \mathrm{C}$ in vacuum using SpeedVac Concentration ((RVC 2-18, Christ). The residue was reconstituted in $100 \mu \mathrm{L}$ acetonitrile and water $(50: 50, v / v)$ and centrifuged at 13,000 rpm $(15,493 \times g)$ for $15 \mathrm{~min}$.

\subsubsection{Calibration Samples and Quality Control Samples}

The stock solutions of magnoflorine, $\alpha$-allocryptopine and skimmianine were prepared in acetonitrile at $1.06,1.02$, and $0.98 \mathrm{mg} / \mathrm{mL}$, respectively. A serious of working solutions were obtained by diluting with acetonitrile. The IS solution was prepared at a concentration of $200 \mathrm{ng} / \mathrm{mL}$ in acetonitrile.

The calibration working solution were prepared by spiking the working solution into blank plasma to obtain concentrations ranges from $2-200 \mathrm{ng} / \mathrm{mL}$ for magnoflorine and $\alpha$-allocryptopine, from $0.5-50 \mathrm{ng} / \mathrm{mL}$ for skimmianine. Quality control (QC) samples were obtained at 5, 50, $160 \mathrm{ng} / \mathrm{mL}$ for magnoflorine and $\alpha$-allocryptopine, at 1, 10, $32 \mathrm{ng} / \mathrm{mL}$ for skimmianine. 


\subsection{Method Validation}

Validation of the analytical method was assessed on selectivity, linearity, sensitivity, accuracy, precision, recovery, matrix effect, and stability according to Pharmacopoeia of the People's Republic of China 2015 guidelines.

The selectivity was assessed by analyzing the chromatograms of blank plasma of six different rats, a blank plasma with magnoflorine, $\alpha$-allocryptopine, skimmianine and IS, and a plasma after dose. The linearity was determined by plotting the peak areas ratios (y) of each analyte to IS against the concentrations, and evaluated by least-squares linear regression. The lower limit of quantification (LLOQ) was defined as the lowest concentration point of the calibration curve $(\mathrm{S} / \mathrm{N}>10)$ with the accuracy within $\pm 20 \%$ and precision lower than $20 \%$. The accuracy and precision were evaluated by analyzing the six replicate QC samples on the same day (intra-day) and three consecutive days. The accuracy and precision were expressed as relative error (RE\%) and relative standard deviation (RSD\%), respectively. The extraction recovery was determined by comparing peak areas of the extracted QC samples with those of post-extracted spiked samples. The matrix effects was measured by calculated the analytes peak area ratios of post-extracted spiked samples to those of pure work solution. The stability was investigated by analyzing samples stability under diverse storage conditions: three freeze-thaw cycles, $8 \mathrm{~h}$ at $25^{\circ} \mathrm{C},-80{ }^{\circ} \mathrm{C}$ for 40 days and in autosampler for $24 \mathrm{~h}$.

\subsection{Animal Experiments}

Male Sprague-Dawley rats $(250 \pm 20 \mathrm{~g})$ used in this study were provided by the Experimental Animal Center of Guangzhou University of Chinese Medicine. The laboratory animal license number is SCXK 2013-0020. These animals were maintained in an air-conditioned animal facility at $23 \pm 2{ }^{\circ} \mathrm{C}$, with a humidity of $55 \% \pm 5 \%$ and a $12 \mathrm{~h}$ light/dark cycle for 5 days before use. The rats had free access to water and a standard diet. Animal welfare and experimental procedures were strictly in accordance with the guidelines of the Committee on the Care and Use of Laboratory Animals in China and the related ethical regulations of Guangzhou University of Chinese Medicine.

For profile study, twelve rats were randomly divided into 2 group, blank control and experimental groups. Before administration, the rats were fasted for $12 \mathrm{~h}$ but allowed water ad libitum. Z. nitidum decoction was orally administered to experimental group at a dose of $15 \mathrm{~mL} \cdot \mathrm{kg}^{-1}(15 \mathrm{~mL}$ decoction equal to $30 \mathrm{~g}$ crude drug) body weight, while distilled water was orally administered to control group. The rats of experimental group were anesthetized at $0.5 \mathrm{~h}, 1 \mathrm{~h}, 2 \mathrm{~h}, 3 \mathrm{~h}, 4 \mathrm{~h}$, and $6 \mathrm{~h}$ after dose, respectively. The blood samples were collected from aorta abdominalis in heparinized tube. All blood samples were then centrifuged at $3500 \mathrm{rpm}(1274 \times \mathrm{g})$ for $15 \mathrm{~min}$ at $4{ }^{\circ} \mathrm{C}$. Blank plasma samples were prepared following the same procedures. All samples were stored at $-80^{\circ} \mathrm{C}$.

For pharmacokinetic study, six rats were orally administered Z. nitidum decoction at a dose of $5.4 \mathrm{~mL} \mathrm{~kg}^{-1}$ (5.4 mL decoction equal to $10.8 \mathrm{~g}$ crude drug) body weight. The blood samples were collected from orbital vein before dose and $0.17,0.33,0.67,1,2,3,4,6,8,10,12$, and 24 after dose. The blood samples were then centrifuged at $3500 \mathrm{rpm}(1274 \times g)$ for $15 \mathrm{~min}$ at $4{ }^{\circ} \mathrm{C}$. The samples were stored at $-80^{\circ} \mathrm{C}$. Data analysis was performed by Drug and Statistics (DAS) 2.0 software (Mathematical Pharmacology Professional Committee of China, Shanghai, China).

\section{Conclusions}

In this study, the UPLC-Q-TOF-MS/MS method was used to identify the absorbed alkaloids in vivo after oral administration $Z$. nitidum decoction for the first time. The fragmentation pathway of magnoflorine, $\alpha$-allocryptopine and nitidine was proposed, and a total of 19 alkaloids were exactly or tentatively identified in rat plasma after dose, including 2 aporphinoid, 3 protopine, 7 benzophenanthrindine, 7 quinoline alkaloids. Among them, five constituents were reported for the first time in Z. nitidum. In addition, a HPLC-MS/MS method was developed to simultaneous determination of three main absorbed components, including magnoflorine, $\alpha$-allocryptopine, and 
skimmianine for the first time. This HPLC-MS/MS method was applied to pharmacokinetic study after oral administration $Z$. nitidum decoction. These results would be helpful for a better understanding about material basis and function mechanism of Z. nitidum decoction, and also provided important information for the quality control and further pharmacological study.

Supplementary Materials: The following are available online.

Author Contributions: R.Z., H.X. and W.C. designed the research; M.W., J.Q. and L.O. collected the data; A.H., Y.C., Z.Z., J.L. analyzed and interpreted the data; A.H. and H.X. wrote the paper.

Funding: This research was funded by the grants (No. [2013]389) from the central government supports the development of special funds for local colleges and universities in China-Chinese materia medica (Guangdong finance and education).

Conflicts of Interest: The authors declare no conflict of interest.

\section{References}

1. Commission, C.P. Pharmacopoeia of the People's Republic of China; China Medical Science Press: Beijing, China, 2015; pp. 169-170.

2. Chen, W.X.; Qin, Z.H.; Zeng, D.; Han, Z.Z.; Zhan, R.T.; Tan, Y.; Chen, W.W. Comparative Study on Effects of Anti-contusion Injury, Analgesia and Anti-inflammation of Root and Stem of Zanthoxylum nitidum. J. Chin. Med. Mater. 2015, 38, 2358-2363. [CrossRef]

3. Qin, Z.H.; Chen, W.X.; Li, R.L.; Han, Z.Z.; Yang, T.C.; Zhan, R.T.; Chen, W.W. Comparative study on effects of anti-gastritis, gastric mucosal protection and gastrointestinal movement promotion of root and stem of Zanthoxylum nitidum. J. Chin. Med. Mater. 2016, 164-169. [CrossRef]

4. Ishii, H.; Imai, M.; Johji, S.; Tan, S.; Chen, I.-S.; Ishikawa, T. Studies on the Chemical Constituents of Xanthoxylum nitidum (ROXB.) D. C. (Fagara nitida ROXB.). II. Examination of the Chemical Constituents by Membrane Filtration: Identification of Magnoflorine, a Water-Soluble Quaternary Aporphine Alkaloid. Chem. Pharm. Bull. 1994, 42, 108-111. [CrossRef]

5. Ishii, H.; Ishikawa, T.; Akaike, M.; Tohjoh, T.; Toyoki, M.; Ishikawa, M.; Chen, I.S.; Lu, S.T. [Studies on the chemical constituents of rutaceous plants. LIX. The chemical constituents of Xanthoxylum nitidum (Roxb.) D.C. (Fagara nitida Roxb.) (1) Examination of the alkaloidal fraction of the bark]. Yakugaku Zasshi J. Pharm. Soc. Jpn. 1984, 104, 1030-1042. [CrossRef]

6. Deyun, K.; Gray, A.I.; Hartley, T.G.; Waterman, P.G. Alkaloids from an Australian accession of Zanthoxylum nitidum (Rutaceae). Biochem. Syst. Ecol. 1996, 24, 87-88. [CrossRef]

7. Li, D.; Min, Z. Alkaloids from Zanthoxylum nitidum. Chin. J. Nat. Med. 2004, 2, 32-35.

8. Wang, X.; Ma, M.; Ding, L. Chemical constituents of Zanthoxylum nitidum. Chin. Pharm. J. 2008, 43, 253-256.

9. Fan, J.; Li, H.; Wang, B.; Hu, W.; Li, H. Isolation, identification and activity determination on the anti-inflammatory components of roots of Zanthoxylum nitidum. J. Shenyang Pharm. Univ. 2013, 30, 100-131. [CrossRef]

10. Moriyasu, M.; Ichimaru, M.; Nishiyama, Y.; Kato, A. (R)-(+)-isotembetarine, a quaternary alkaloid from Zanthoxylum nitidium. J. Nat. Prod. 1997, 60, 299-301. [CrossRef]

11. Huang, Z.; Li, Z. Studies on the antitumor constituents of Zanthoxylum nitidum (ROXB.) DC. Acta Chim. Sin. 1980, 6, 535-542.

12. Hu, J.; Zhang, W.D.; Shen, Y.H.; Zhang, C.; Xu, L.; Liu, R.H.; Wang, B.; Xu, X.K. Alkaloids from Zanthoxylum nitidum (Roxb.) DC. Biochem. Syst. Ecol. 2007, 35, 114-117. [CrossRef]

13. Wang, M. A study on the chemical constituents of Zanthoxylum nitidum (Lam) DC. Isolation of potential anticancer alkaloids and studies on the structure of alkaloids C. J. Sun Yat-Sen Univ. Med. Sci. 1980, 1, 341-349, 402.

14. Fang, S.D.; Wang, L.K.; Hecht, S.M. Inhibitors of DNA topoisomerase-I Isolated from Zanthoxylun nitidum. J. Org. Chem. 1993, 58, 5025-5027. [CrossRef]

15. Hu, J.; Zhang, W.D.; Liu, R.H.; Zhang, C.; Shen, Y.H.; Li, H.L.; Liang, M.J.; Xu, X.K. Benzophenanthridine alkaloids from Zanthoxylum nitidum (ROXB.) DC, and their analgesic and anti-inflammatory activities. Chem. Biodivers. 2006, 3, 990-995. [CrossRef] 
16. Shen, X.; Mu, S.; Wang, Q.; Xie, X.; Deng, L. Isolation and identification of chemical constituents from the roots of Zanthoxylum nitidum (Roxb.) DC. in Yunan province. J. Shenyang Pharm. Univ. 2016, 33, 275-279, 292. [CrossRef]

17. Zhao, L.-N.; Wang, J.; Wang, Z.; Tan, N.-H. Chemical and cytotoxic constituents of Zanthoxylum nitidum. China J. Chin. Mater. Med. 2018, 1-7. [CrossRef]

18. Yang, G.; Chen, D. Alkaloids from the roots of Zanthoxylum nitidum and their antiviral and antifungal effects. Chem. Biodivers. 2008, 5, 1718-1722. [CrossRef] [PubMed]

19. Cui, X.G.; Zhao, Q.J.; Chen, Q.L.; Xu, L.; Song, Y.; Jin, Y.S.; Xu, D.F. Two new benzophenanthridine alkaloids from Zanthoxylum nitidum. Helv. Chim. Acta 2008, 91, 155-158. [CrossRef]

20. Yang, C.H.; Cheng, M.J.; Chiang, M.Y.; Kuo, Y.H.; Wang, C.J.; Chen, I.S. Dihydrobenzo[c]phenanthridine alkaloids from stem bark of Zanthoxylum nitidum. J. Nat. Prod. 2008, 71, 669-673. [CrossRef] [PubMed]

21. Jia, C.; Huang, X.; Li, Y.; Feng, F. Analysis of alkaloids in Zanthoxylum nitidum by HPLC-DAD/ESI-Q-TOF-MS. China J. Chin. Mater. Med. 2013, 38, 1198-1202. [CrossRef]

22. Yang, P.; Qing, Z.; Xiang, F.; Mo, C.; Tang, Q. Identification of alkaloids in Zanthoxylum nitidum and Zanthoxylum dissitum by HPLC-Q-TOF /MS. Chin. Tradit. Pat. Med. 2017, 39, 1646-1650. [CrossRef]

23. Qin, Z.; Dai, Y.; Yao, Z.; He, L.; Wang, Q.; Geng, J.; Chen, H.; Yao, X. Study on chemical profiles and metabolites of Allii Macrostemonis Bulbus as well as its representative steroidal saponins in rats by ultra-performance liquid chromatography coupled with quadrupole time-of-flight tandem mass spectrometry. Food Chem. 2016, 192, 499-515. [CrossRef]

24. Lin, P.; Qin, Z.; Yao, Z.; Wang, L.; Zhang, W.; Yu, Y.; Dai, Y.; Zhou, H.; Yao, X. Metabolites profile of Gualou Xiebai Baijiu decoction (a classical traditional Chinese medicine prescription) in rats by ultra-performance liquid chromatography coupled with quadrupole time-of-flight tandem mass spectrometry. J. Chromatogr. B Anal. Technol. Biomed. Life Sci. 2018, 1085, 72-88. [CrossRef] [PubMed]

25. Qing, Z.X.; Cheng, P.; Liu, X.B.; Liu, Y.S.; Zeng, J.G.; Wang, W. Structural speculation and identification of alkaloids in Macleaya cordata fruits by high-performance liquid chromatography / quadrupole-time-of-flight mass spectrometry combined with a screening procedure. Rapid Commun. Mass Spectrom. 2014, 28, 1033-1044. [CrossRef]

26. Zhang, F.X.; Li, M.; Yao, Z.H.; Li, C.; Qiao, L.R.; Shen, X.Y.; Yu, K.T.; Dai, Y.; Yao, X.S. A target and nontarget strategy for identification or characterization of the chemical ingredients in Chinese herb preparation Shuang-Huang-Lian oral liquid by ultra-performance liquid chromatography-quadrupole time-of-flight mass spectrometry. Biomed. Chromatogr. 2018, 32. [CrossRef] [PubMed]

27. Huang, A.; Xu, H.; Zhan, R.; Chen, W.; Liu, J.; Chi, Y.; Chen, D.; Ji, X.; Luo, C. Metabolic Profile of Skimmianine in Rats Determined by Ultra-Performance Liquid Chromatography Coupled with Quadrupole Time-of-Flight Tandem Mass Spectrometry. Molecules 2017, 22, 489. [CrossRef] [PubMed]

28. Stevigny, C.; Jiwan, J.L.; Rozenberg, R.; de Hoffmann, E.; Quetin-Leclercq, J. Key fragmentation patterns of aporphine alkaloids by electrospray ionization with multistage mass spectrometry. Rapid Commun. Mass Spectrom. 2004, 18, 523-528. [CrossRef] [PubMed]

29. Tian, X.; Zhang, Y.; Li, Z.; Hu, P.; Chen, M.; Sun, Z.; Lin, Y.; Pan, G.; Huang, C. Systematic and comprehensive strategy for metabolite profiling in bioanalysis using software-assisted HPLC-Q-TOF: Magnoflorine as an example. Anal. Bioanal. Chem. 2016, 408, 2239-2254. [CrossRef]

30. Qing, Z.; Cheng, P.; Zeng, J. Research progress on mass spectral fragmentation behaviour of alkaloids in Macleaya cordata. Chin. Tradit. Herb. Drugs 2013, 2929-2939. [CrossRef]

31. Qing, Z.; Cheng, P.; Liu, X.; Liu, Y.; Zeng, J. Systematic identification of alkaloids in Macleaya microcarpa fruits by liquid chromatography tandem mass spectrometry combined with the isoquinoline alkaloids biosynthetic pathway. J. Pharm. Biomed. Anal. 2015, 103, 26-34. [CrossRef]

32. Cong, P.; Li, S. Mass Spectrometry of Natural Products; China Medicine Science and Technology Press: Beijing, China, 2003; p. 191.

33. Atta ur, R.; Khalid, A.; Sultana, N.; Ghayur, M.N.; Mesaik, M.A.; Khan, M.R.; Gilani, A.H.; Choudhary, M.I. New natural cholinesterase inhibiting and calcium channel blocking quinoline alkaloids. J. Enzym. Inhib. Med. Chem. 2006, 21, 703-710. [CrossRef]

34. Li, L.P. The Role of Organic Cation Transportes and CYPs in the Transportation and Toxicity of Nitidine Chloride. Ph.D. Thesis, Zhejiang University, Hangzhou, China, 2014. 
35. Zhou, Q.H.; Liu, Y.P.; Wang, X.; Di, X. A sensitive and selective liquid chromatography-tandem mass spectrometry method for simultaneous determination of five isoquinoline alkaloids from Chelidonium majus L. in rat plasma and its application to a pharmacokinetic study. J. Mass Spectrom. 2013, 48, 111-118. [CrossRef] [PubMed]

36. Cai, Z.; Feng, Y.; Li, C.; Yang, K.; Sun, T.; Xu, L.; Chen, Y.; Yan, C.-H.; Lu, W.W.; Chiu, K.-Y. Magnoflorine with hyaluronic acid gel promotes subchondral bone regeneration and attenuates cartilage degeneration in early osteoarthritis. Bone 2018, 116, 266-278. [CrossRef] [PubMed]

37. Guo, S.; Jiang, K.; Wu, H.; Yang, C.; Yang, Y.; Yang, J.; Zhao, G.; Deng, G. Magnoflorine Ameliorates Lipopolysaccharide-Induced Acute Lung Injury via Suppressing NF-kappa B and MAPK Activation. Front. Pharmacol. 2018, 9. [CrossRef]

38. Haque, M.A.; Jantan, I.; Harikrishnan, H.; Abdul Wahab, S.M. Magnoflorine Enhances LPS-Activated Pro-Inflammatory Responses via MyD88-Dependent Pathways in U937 Macrophages. Planta Med. 2018, 84, 1255-1264. [CrossRef]

39. Li, C.; Wang, M.-H. Potential Biological Activities of Magnoflorine: A Compound from Aristolochia debilis Sieb. et Zucc. Korean J. Plant Resour. 2014, 27, 223-228. [CrossRef]

40. Fu, Y.-C.; Zhang, Y.; Tian, L.-Y.; Li, N.; Chen, X.; Cai, Z.-Q.; Zhu, C.; Li, Y. Effects of allocryptopine on outward potassium current and slow delayed rectifier potassium current in rabbit myocardium. J. Geriatr. Cardiol. 2016, 13, 316-325. [CrossRef]

41. Xu, B.; Fu, Y.; Liu, L.; Lin, K.; Zhao, X.; Zhang, Y.; Chen, X.; Cai, Z.; Huang, Y.; Li, Y. Effect of alpha-Allocryptopine on Delayed Afterdepolarizations and Triggered Activities in Mice Cardiomyocytes Treated with Isoproterenol. Evid.-Based Complement. Altern. Med. 2015, 2015, 634172. [CrossRef]

42. Zhang, J.; Chen, Y.; Yang, J.; Xu, B.; Wen, Y.; Xiang, G.; Wei, G.; Zhu, C.; Xing, Y.; Li, Y. Electrophysiological and trafficking defects of the SCN5A T353I mutation in Brugada syndrome are rescued by alpha-allocryptopine. Eur. J. Pharmacol. 2015, 746, 333-343. [CrossRef]

43. Ratheesh, M.; Sindhu, G.; Helen, A. Anti-inflammatory effect of quinoline alkaloid skimmianine isolated from Ruta graveolens L. Inflamm. Res. 2013, 62, 367-376. [CrossRef]

44. Chang, Z.Q.; Wang, S.L.; Hao, C.Y.; Liu, F.; Bian, C.F.; Chen, J.M. Analgesic, antispastic and sedative effects of skimmianine. Zhongguo Yao Li Xue Bao Acta Pharmacol. Sin. 1982, 3, 163-165.

45. Yang, Z.D.; Zhang, D.B.; Ren, J.; Yang, M.J. Skimmianine, a furoquinoline alkaloid from Zanthoxylum nitidum as a potential acetylcholinesterase inhibitor. Med. Chem. Res. 2012, 21, 722-725. [CrossRef]

Sample Availability: Samples of the compounds are not available from the authors.

(C) 2019 by the authors. Licensee MDPI, Basel, Switzerland. This article is an open access article distributed under the terms and conditions of the Creative Commons Attribution (CC BY) license (http://creativecommons.org/licenses/by/4.0/). 